\title{
МОДИФІКАЦІЙНИЙ ВПЛИВ НА ЯКІСТЬ ТА ДОВГОВІЧНІСТЬ НАСІННЯ ПОЛЬОВИХ КУЛЬТУР
}

\author{
Н. В.НОВИЦьКА, кандидат сільськогосподарських наук, \\ доцент кафедри рослинництва \\ ORCID https://orcid.org/0000-0002-7645-4151
}

Національний університет біоресурсів і природокористування України

E-mail: novictska@ukr.net

\begin{abstract}
Анотація. Довговічність насіння озимих зернових культур у значній мірі залежить від умов вирощування, збирання й післязбиральної доробки, а також від впливу інших модифікуючих чинників, таких як проростання на корені, вилягання рослин, пошкодження мікроорганізмами, фрізичних та інших впливів. Метою досліджень було вивчення модифрікаційного впливу (погодних умов, видових особливостей, строків та способів збирання) на якість та довговічність насіння озимих зернових культур. Насіння жита озимого сорту Сіверське та пшениці озимої сорту Поліська 90 урожаю 2006 та 2007 років було зібране в різні фази стиглості, вручну та механізовано, висушене до вологості $13 \%$, закладено на зберігання в герметичній тарі за пониженої температури повітря $\left(+5{ }^{\circ} \mathrm{C}\right)$ в умовах лабораторії "Якості насіння та садивного матеріалу» кафредри рослинництва НУБіП України. Упродовж десяти наступних років визначали енергію проростання, лабораторну схожість та вологості насіння згідно діючих методик ДСТУ 4138-2002. Встановлено, що за несприятливих погодних умов фрормування зростає відсоток слабкого, недорозвиненого $i$ гіпертрофованого насіння, в 1,5-2 рази знижується господарська, проте мало змінюється біологічна довговічність, повністю не знижується період стійкого зберігання посівних якостей. Модифікаційна мінливість насіння в результаті прямого впливу на нього технологічних прийомів збирання в більшості випадків більш суттєво, ніж несприятливі умови формування, погіршують посівні якості та довговічність насіння. Перестій на корені викликає різке погіршення посівних якостей та довговічності насіння озимих зернових, повну втрату періоду стійкого зберігання та значне зниження схожості в перший же рік зберігання. Однотипове за біологічними властивостями насіння жита та пшениці з різною вихідною схожість за рахунок травмування у разі механізованого збирання характеризується різною господарською, проте, подібною біологічною довговічністю.
\end{abstract}

Ключові слова: пшениця озима, жито озиме, насіння, погодні умови, строки збирання, способи збирання, зберігання, лабораторна схожість, довговічність 


\section{Bcmyn.}

Довговічність насіння в науковому аспекті означає його здатність зберігати життєздатність упродовж певного часу, тобто під довговічністю розуміють тривалість життя насіння. Вона зумовлюється як біологічними особливостями культури, так й умовами, що складаються в процесі зберігання насіння. Існуюча класифікація поділяє довговічність насіння на біологічну, господарську та генетичну. Біологічна довговічність - це проміжок часу, впродовж якого в насіннєвому матеріалі зберігається схожість хоч однієї насінини. У звичайних умовах зберігання біологічна довговічність насіння сільськогосподарських культур не перевищує 10-15 років. Під господарською довговічністю розуміють проміжок часу, упродовж якого насіння зберігає схожість, яка відповідає чинним вимогам стандартів на посівний матеріал. Господарська довговічність насіння в зоні помірного клімату визначається двома-трьома роками, зрідка досягає чотирьох-п'яти років. Знання господарської довговічності важливе під час створення страхових насіннєвих фондів (Жатова Г. О., 2009; Каленська с. М., Новицька С. М., Жемойда В.Л., 2011). Довговічність у значній мірі залежить від навколишніх умов формування насіння, оптимум яких для різних видів неоднаковий, i, можна стверджувати, остаточно не визначений. Крім того, у багатьох видів рослин довговічність насіння переважає 100 років і для іiі визначення необхідна праця кількох поколінь вчених, тому ці факти остаточно не досліджені (Гаврилюк М. М., 2004; Бугайов В.В., 2012).

\section{Аналіз останніх досліджень ма публікацій.}

У науковій літературі є досить багато відомостей про те, що довговічність насіння конкретної культури й сорту у значній мірі залежить від умов вирощування, збирання й післязбиральної доробки, а також від впливу інших модифікуючих чинників, таких як проростання на корені, вилягання рослин, пошкодження мікроорганізмами, фізичних та інших впливів. Роль деяких iз них, наприклад, строків збирання та стиглості насіння, широко відображена в літературі, тоді як про значення інших чинників $є$ лише уривчасті відомості. У спеціальній літературі є свідчення про те, що збирання до настання воскової стиглості знижує польову схожість і силу росту насіння, а також їхню стійкість під час зберігання (Фадеев Л. В., 2018). Насіння озимого жита, зібране з вологістю $42 \%$, після двох років зберігання помітно поступалося за схожістю насінню, зібраному за воскової стиглості (Строна И.Г., 1972). Разом із тим, деякі автори відзначають, що строки збирання зернових не є вирішальним чинником у збереженні життєздатності насіння і що можливе отримання доброякісного насіння пшениці та жита за збирання до настання воскової стиглості (Силаева О.И., 2012; Задорожна О. А., Шиянова Т.П., Герасимов М. В., 2014). Однак перевірка довговічності насіння в цих дослідах не проводилася. У публікаціях висловлюється одностайна думка про меншу довговічність насіння озимого жита в порівнянні із пшеницею. Озиме жито віднесене до групи мікробіотиків із періодом господарської довговічності 1-3 роки, тоді як насіння пшениці включене в групу мезобіотиків, здат- 
них підтримувати високий рівень схожості впродовж 15 років. Однак у практиці насінництва, в діючих інструкціях і стандартах ці відмінності не завжди враховуються. Встановлено єдиний трирічний термін допустимого зберігання сухого насіння пшениці та жита. У стандартах на насіння цих культур до останнього часу були однакові зональні вимоги за рівнем вологості, схожості та іншими показниками (Задорожна О. А., Шиянова Т.П., Герасимов М. В., 2014; ДСТУ 41382002 Насіння сільськогосподарських культур. Методи визначення якості).

Метою досліджень було вивчення модифікаційного впливу (погодних умов, видових особливостей, строків та способів збирання) на якість та довговічність насіння озимих зернових культур.

\section{Матеріали і методи досліджень.}

Матеріалом для багаторічного (2006 - 2016 рр.) лабораторного досліду було насіння озимих зернових культур, вирощене у стаціонарному досліді кафедри рослинництва на полях ВП НУБіП України «Агрономічна дослідна станція». Насіння жита озимого сорту Сіверське та пшениці озимої сорту Поліська 90 урожаю 2006 та 2007 років було зібране в різні фаз стиглості, вручну та механізовано, висушене до вологості $13 \%$, закладено на зберігання в герметичній тарі за пониженої температури повітря $\left(+5^{\circ} \mathrm{C}\right)$ в умовах лабораторії «Якості насіння та садивного матеріалу» кафедри рослинництва НУБіП України. Кожного року з партій відбирали середні проби насіння для визначення їх посівних якостей згідно діючих методик ДСТУ 4138-2002
(ДСТУ 4138-2002 Насіння сільськогосподарських культур. Методи визначення якості).

\section{Результати досліджень та їх обговорення.}

Отримані нами результати дозволяють уточнити уявлення про довговічність насіння озимих зернових культур, вирощених в умовах Лісостепу України. Середній період життєздатності (зниження схожості до $50 \%$ ) насіння жита озимого склав 7 років і пшениці приблизно 9 років. Проведений нами порівняльний аналіз тривалого 10-річного зберігання насіння різних видів засвідчив суттєву різницю збереження посівних якостей залежно від хімічного складу. Відмінності за стійкістю насіння озимої пшениці та жита в перший рік зберігання виявилися несуттєвими. Середнє зниження схожості насіння пшениці на другий рік зберігання склало 0,7\% за сприятливого року для його формування та 1,7 \% - за несприятливого. У насіння жита озимого відповідне зниження досягало 1,2 та 2,5\%. Різниця у зниженні схожості між культурами наростала поступово і стала суттєвою лише через 6-7 років за іiі значення в межах 70-80 \%.

Під час визначення господарської довговічності неможливо зробити однозначний висновок про гіршу збереженість насіння жита. У сприятливому за умовами дозрівання 2007 році насіння жита і пшениці мало практично однаковий і досить тривалий період господарської довговічності. Воно зберігало кондиційну схожість приблизно чотири роки. Однак в подальшому їі зниження в насіння жита відбувалося помітно швидше, ніж у пшениці (табл. 1). 


\section{1. Динаміка лабораторної схожості насіння пшениці озимої та жита озимого за тривалого зберігання (механізоване збирання)}

\begin{tabular}{|c|c|c|c|c|}
\hline \multirow{2}{*}{$\begin{array}{l}\text { Тривалість } \\
\text { зберігання, } \\
\text { рік }\end{array}$} & \multicolumn{2}{|c|}{ Лабораторна схожість насіння, \% } & \multicolumn{2}{|c|}{ Зниженні схожості, \% } \\
\hline & \begin{tabular}{|c|}
$\begin{array}{c}\text { жито озиме, сорт } \\
\text { Сіверське }\end{array}$ \\
\end{tabular} & $\begin{array}{l}\text { пшениця озима, } \\
\text { сорт Поліська } 90\end{array}$ & жито озиме & пшениця озима \\
\hline \multicolumn{5}{|c|}{ Урожай 2006 року (рік відносно несприятливий) } \\
\hline 0 & 92,8 & 93,4 & - & - \\
\hline 2 & 90,3 & 91,7 & 2,5 & 1,7 \\
\hline 3 & 88,2 & 90,6 & 4,6 & 2,8 \\
\hline 5 & 81,8 & 86,2 & 11,0 & 7,2 \\
\hline 6 & 68,6 & 77,4 & 24,2 & 16,0 \\
\hline 8 & 16,2 & 65,2 & 76,6 & 28,2 \\
\hline 10 & 2,1 & 28,4 & 90,7 & 65,0 \\
\hline \multicolumn{5}{|c|}{ Урожай 2007 року (рік відносно сприятливий) } \\
\hline 0 & 92,9 & 93,6 & - & - \\
\hline 2 & 91,7 & 92,9 & 1,2 & 0,7 \\
\hline 3 & 90,6 & 90,6 & 2,3 & 3,0 \\
\hline 5 & 89,6 & 88,7 & 3,3 & 4,9 \\
\hline 6 & 63,6 & 72,8 & 29,3 & 20,8 \\
\hline 8 & 41,3 & 70,3 & 51,6 & 23,3 \\
\hline 10 & 2,6 & 42,6 & 90,3 & 51,0 \\
\hline
\end{tabular}

Насіння пшениці озимої, отриманого в менш сприятливі роки, має певну перевагу під час зберігання. Так, насіння жита озимого, зібране в 2006 році (дуже сухі й холодні червень та липень - сума опадів в ці місяці була на 84 та 35 \% менше норми на даний період) швидко втрачає схожість і, відповідно, довговічність. Зниження якості насіння пояснюється посиленням травмування, значним збільшенням негативної дії мікроорганізмів, у першу чергу, пліснявих грибів.

Залежно від фази достигання культури, за якої збирали насіння, кращою для озимих культур виявилася воскова стиглість. Аналіз отриманих нами результатів не дозволяє однозначно характеризувати властивості й довговічність насіння ранніх строків збирання (молочна стиглість). Виявлено, що ранні строки збирання озимих зернових викликають недобір маси сухої речовини в перерахунку на 1000 насінин і більш суттєве погіршення їх якості під час зберігання (табл. 2).

Істотні відмінності схожості насіння жита озимого молочного стиглості 3 недобором 10-15 \% маси сухої речовини в порівнянні з насінням воскової стиглості простежуються впродовж наступних 4-8 років зберігання, в залежності від погодних умов е рік вирощування. Звертає на себе увагу той факт, що насіння надранніх строків збирання має максимально високу схожість 96-98 \%. Але оскільки воно менш довговічне, є підстави стверджувати, що найважливіший показник посівних якостей насіння - високий рівень схожості - не завжди харак- 


\section{2. Динаміка лабораторної схожості насіння пшениці озимої та жита озимого за різних строків збирання (2006 рік, ручне збирання)}

\begin{tabular}{|l|c|c|c|c|c|}
\hline \multirow{2}{*}{ Показники } & \multicolumn{5}{|c|}{ Фаза достигання (стиглість) } \\
\cline { 2 - 6 } & молочна & $\begin{array}{c}\text { тістопо- } \\
\text { дібна }\end{array}$ & воскова & повна & $\begin{array}{c}\text { перестій } \\
\text { на корені }\end{array}$ \\
\hline \multicolumn{5}{|c|}{ Пшениця озима Поліська 90 } \\
\hline Маса 1000 насінин, г & 41,3 & 42,2 & 46,1 & 46,6 & 43,9 \\
\hline Лабораторна схожість, \% & 98 & 96 & 95 & 94 & 86 \\
\hline $\begin{array}{l}\text { Зниження схожості } \\
\text { за 1 рік зберігання, \% }\end{array}$ & 1 & 1 & 0 & 0 & 2 \\
\hline 3 & 1 & 1 & 0 & 2 & 9 \\
\hline 5 & 5 & 2 & 3 & 4 & 24 \\
\hline 8 & 68 & 16 & 12 & 21 & 71 \\
\hline 10 & 88 & 50 & 37 & 46 & 98 \\
\hline \multicolumn{7}{|c|}{ Жито озиме Сіверське } & & \\
\hline Маса 1000 насінин, г & 26,4 & 29,8 & 30,9 & 30,7 & 30,0 \\
\hline Лабораторна схожість, \% & 95 & 94 & 94 & 93 & 84 \\
\hline $\begin{array}{l}\text { 3ниження схожості } \\
\text { за 1 рік зберігання, \% }\end{array}$ & 0 & 1 & 1 & 2 & 26 \\
\hline 3 & 3 & 3 & 2 & 5 & 52 \\
\hline 5 & 14 & 7 & 6 & 11 & 68 \\
\hline 8 & 81 & 61 & 54 & 59 & 97 \\
\hline 10 & 98 & 92 & 91 & 91 & 100 \\
\hline
\end{tabular}

теризує тривалість його зберігання. Після дозрівання й перестої на корені насіння озимих пшениці й жита хоч і мало відносно високу схожість (86 та 84 \%) і цілком задовільну стійкість під час зберігання, проте, воно виявилося менш довговічним, ніж насіння зібране у фазу воскової стиглості. Лабораторна схожість такого насіння суттєво знижувалася $з$ перших років зберігання і на 10 рік аналізування втрачалася на $98 \%$ у пшениці озимої та на $100 \%$ у жита озимого.

Нами досліджено біологічну довговічність насіння різних видів залежно від способу збирання культур та їх тривалого зберігання. Встановлено, що довговічність насіння після механізованого збирання значно нижча, а початковий темп втрати схожості дещо вищий, ніж у зразків насіння після ручного обмолочування. Різниця у втраті схожості зростає поступово й досягає найбільшої величини через 6-8 років. Найбільша різниця зниження схожості насіння пшениці та жита ручного та механізованого збирання становить 11$15 \%$. Насіння озимих зернових після ручного й механізованого збирання втрачає довговічність майже одночасно, через 8-10 років у жита і на 1-2 роки пізніше у пшениці (за такого режиму зберігання). У результаті біологічна довговічність однотипного насіння незалежно від способу збирання приблизно однакова (табл. 3).

Зовсім іншими чинниками визна- 


\section{3. Динаміка лабораторної схожості насіння пшениці озимої та жита озимого за різних способів збирання (2006 рік збирання)}

\begin{tabular}{|l|c|c|c|c|c|c|}
\hline \multirow{2}{*}{ Показники } & \multicolumn{3}{|c|}{ Жито озиме Сіверське } & \multicolumn{3}{|c|}{ Пшениця озима Поліська 90 } \\
\cline { 2 - 7 } & $\begin{array}{c}\text { ручне } \\
\text { збирання }\end{array}$ & $\begin{array}{c}\text { механі- } \\
\text { зоване } \\
\text { збирання }\end{array}$ & різниця & $\begin{array}{c}\text { ручне } \\
\text { збирання }\end{array}$ & $\begin{array}{c}\text { механі- } \\
\text { зоване } \\
\text { збирання }\end{array}$ & різниця \\
\hline $\begin{array}{l}\text { Лабораторна } \\
\text { схожість, \% }\end{array}$ & 98 & 94 & - & 99 & 96 & 3 \\
\hline $\begin{array}{l}\text { Зниження схо- } \\
\text { жості за 1 рік } \\
\text { зберігання, \% }\end{array}$ & 0 & 1 & 1 & 0 & 1 & 1 \\
\hline 3 & 1 & 4 & 3 & 0 & 2 & 2 \\
\hline 5 & 4 & 10 & 6 & 0 & 6 & 6 \\
\hline 6 & 9 & 24 & 15 & 1 & 13 & 12 \\
\hline 8 & 54 & 60 & 6 & 10 & 22 & 12 \\
\hline 10 & 80 & 85 & 5 & 58 & 63 & 5 \\
\hline
\end{tabular}

чається господарська довговічність насіння. Вона залежить не тільки від виду, але й від початкового рівня схожості насіння, того запасу якості, який можливо втратити під час зберігання в межах вимог стандарту на насіння. Механізоване збирання збільшує відсоток травмованого насіння і знижує початкову схожість насіння. Під час тривалого зберігання таких зразків насіння схожість насіння жита озимого на 8 рік знижується на $60 \%$, на 10 рік - на $85 \%$, пшениці озимої - на 22 та $63 \%$. Внаслідок комплексного впливу травмування під час збирання та подальшого розвитку збудників захворювань господарська довговічність насіння, зібраного комбайном, скорочується майже вдвічі з 5-6 до 2,5-3 років у жита, і приблизно 37 до 3-4 років у пшениці. Механічні пошкодження насіння помітно погіршують їхню стійкість під час зберігання, як правило в 1,5-2 рази знижують господарську довговічність, але мало позначаються на біологічній довговічності насіннєвих партій. Остання залежить від властивостей непошкод- женого насіння, яке є в партіях після механізованого збирання.

\section{Висновки.}

Багаторічні дослідження модифікаційного впливу (погодних умов, видових особливостей, строків та способів збирання) на якість та довговічність насіння озимих зернових культур дозволили встановити, що ранжування насіння за довговічністю значно залежить від погодних умов вирощування. За несприятливих погодних умов формування зростає відсоток слабкого, недорозвиненого i гіпертрофованого насіння, у 1,5-2 рази знижується господарська, проте, мало змінюється біологічна довговічність, повністю не знижується період стійкого зберігання посівних якостей. Модифікаційна мінливість насіння в результаті прямого впливу на нього технологічних прийомів збирання в більшості випадків більш суттєво, ніж несприятливі умови формування, погіршують посівні якості та довговічність насіння. Перестій на корені 
викликає різке погіршення посівних якостей та довговічності насіння озимих зернових, повну втрату періоду стійкого зберігання та значне зниження схожості в перший же рік зберігання. Однотипове за біологічними властивостями насіння жита та пшениці з різною вихідною схожість за рахунок травмування за механізованого збирання характеризується різною господарською, проте подібною біологічною довговічністю.

\section{References}

1. Zhatova, H. O. (2009) Zahalne nasinnieznavstvo [General Seed Science]. Sumy: Universytetska knyha. [in Ukrainian].

2. Kalenska, S. M., Novytska, N. V. \& Zhemoida, V. L. (2011). Nasinnieznavstvo ta metody vyznachennia yakosti nasinnia silskohospodarskykh kultur [Seed Science and Methods for Determining the Quality of Seeds of Agricultural Crops]. Vinnytsia: FOP Danyliuk. [in Ukrainian].

3. Havryliuk, M. M. (2004). Osnovy suchasnoho nasinnytstva [Fundamentals of Modern Seed Production]. K.: NNTS IAE. [in Ukrainian].

4. Buhaiov, V. V. (2012). Dynamics of similarity of seeds of cereal perennial grasses during storage. Kormy i kormovyrobnytstvo [Feed and Feed Production]. 74. 36-41. [in Ukrainian].

5. Fadeev, L. V. (2018). Ways of increasing the yield and improving the safety of grain during storage. Hranenie i pererabotka zerna. [Storage and Processing of Grain]. Retrieved from http://hipzmag. com/tehnologii/hranenie/puti-povysheniya-urozhajnosti-i-uluchsheniya-sohrannosti-zerna-pri-hranenii/ [in Russian].

6. Strona, I. G. (1972). Travmirovanie semjan i ego preduprezhdenie [Seed Injury and Prevention]. Moscow: Kolos. [in Russian].

7. Silayeva, O. I. (2012). Storage of a collection of the world plant resources of seeds at low positive temperatures - assessment, state, prospects. Trudy po Prikladnoy Botanike, Genetike i Selektsyi. [Proceedings on Applied Botany, Genetics and Breeding]. 169 (3). 230-239. [in Russian].

8. Zadorozhna, O. A, Shyianova, T. P. \& Herasimov, M. V. (2014). Features of longterm storage of seeds of the rye gene pool accessions. Henetychni Resursy Roslyn. [Plant Genetic Resources]. 14. 105-114. [in Russian].

9. Merchalova, M. Je., Orobinskij, V. I. \& Tarasenko, A. P. (2016). The dependence of the quality of seeds of winter wheat on the method and duration storage. Vestnik Voronezhskogo gosudarstvennogo agrarnogo universiteta. [Bulletin of the Voronezh State Agrarian University]. 3(50). 127-131. [in Russian].

10. Nasinnia silskohospodarskykh kultur: Metody vyznachennia yakosti: DSTU 4138: 2002. [Seeds of agricultural crops: Methods for determining quality: State Standard 4138: 2002]. (2003). Kyiv: Derzhstandart Ukrainy. [in Ukrainian].

\section{N. V. Novytska (2019). MODIFICATION EFFECT ON QUALITY AND LONGEVITY \\ OF FIELD CROPS SEEDS. PLANT AND SOIL SCIENCE, 10(3): 12-19.}

https://doi.org/10.31548/agr2019.03.012

Annotation. Longevity of winter crops seeds largely depends on growing conditions, harvesting and post-harvest handling, as well as the influence of other modifying factors, such as root germination, plant lodging, damage by microorganisms, physical and other influences. The purpose of research was to study modification impact (weather conditions, species peculiarities, terms and methods of collection) on quality and durability of seeds of winter grain crops. Seeds of winter rye variety Siverske and winter 
wheat variety Poliska 90 of harvest 2006 and 2007 were collected in various phases of ripeness, manually and mechanized, dried to moisture content $13 \%$, stored in an airtight container at low air temperature $\left(+5^{\circ} \mathrm{C}\right)$ in conditions of laboratory "Quality of seeds and planting material» of Plant Science Department of NULES of Ukraine. Ten subsequent years was determined energy of germination, laboratory germination and seed moisture according to the existing methods DSTU 4138-2002. Has been established that under unfavorable weather conditions of formation, percentage of weak, underdeveloped and hypertrophied seeds grows by 1,5-2 times, economic longevity decreases, but biological longevity changes a little, period of stable saving of sowing qualities does not decrease. The modification variability of seeds as result of direct impact on it by harvesting methods in most cases is more significant that unfavorable conditions of formation, worsen sowing qualities and longevity of seeds. Overripe causes a sharp deterioration of sowing qualities and longevity of winter cereals seeds, a complete loss of period of stable saving and significant reduction of germination in the first year of storage. The biological properties of rye and wheat seeds of different initial germination due to injury during mechanized harvesting are characterized by different economic, but similar biological longevity.

Keywords: winter wheat, winter rye, seeds, weather conditions, time of harvesting, methods of harvesting, storage, laboratory germination, longevity 